\title{
EDITORIAL
}

Open Access

\section{Publisher's Note to Volumes 32 and 33}

Egyptian Journal of Neurosurgery

The Egyptian Journal of Neurosurgery was transferred to Springer Nature in 2018. The last volume published was Volume 31. The first volume published by Springer Nature should have been Volume 32, but due to a technical error by the publisher, this was published as Volume 33 of the journal. For bibliographic and indexing purposes, Volume 32 of this journal will be skipped.

\section{Author's contributions}

The author read and approved the final manuscript.

Published online: 11 December 2019

\section{Publisher's Note}

Springer Nature remains neutral with regard to jurisdictional claims in published maps and institutional affiliations. journal and benefit from:

- Convenient online submission

- Rigorous peer review

- Open access: articles freely available online

- High visibility within the field

- Retaining the copyright to your article 